\title{
Growth and Hematological Performances of Broilers Fed on Meal and Protein Isolate of Mucuna pruriens Seeds
}

\author{
Mweugang Ngouopo Nathalie ${ }^{1,}$, , Miegoue Emile ${ }^{2}$, Djitie Kouatcho Francois ${ }^{1}$, Yacouba Manga ${ }^{1}$, \\ Pelyang Maurice ${ }^{1}$, Youssoufa Tchoubou ${ }^{1}$, Madjou Solange ${ }^{1}$, Njintang Yanou Nicolas ${ }^{1}$, \\ Pamo Tedonkeng Etienne ${ }^{2}$ \\ ${ }^{1}$ Department of Biological Sciences, Faculty of Sciences, University of Ngaoundere, Ngaoundere, Cameroon \\ ${ }^{2}$ Animal Nutrition and Production Research Unit, Department of Animal Production, Faculty of Agronomy and Agricultural Sciences, \\ University of Dschang, Dschang, Cameroon
}

\section{Email address:}

nathaliemweugang@yahoo.fr (M. N. Nathalie),nathalie.mweugang@univ-ndere.cm (M. N. Nathalie)

${ }^{*}$ Corresponding author

\section{To cite this article:}

Mweugang Ngouopo Nathalie, Miegoue Emile, Djitie Kouatcho Francois, Yacouba Manga, Pelyang Maurice, Youssoufa Tchoubou, Madjou Solange, Njintang Yanou Nicolas, Pamo Tedonkeng Etienne. Growth and Hematological Performances of Broilers Fed on Meal and Protein Isolate of Mucuna pruriens Seeds. Animal and Veterinary Sciences. Vol. 8, No. 6, 2020, pp. 117-123. doi: 10.11648/j.avs.20200806.11

Received: October 7, 2020; Accepted: October 26, 2020; Published: November 11, 2020

\begin{abstract}
The potential for the utilization of Mucuna seeds as an alternative source of protein was evaluated by presoaking in water then in sodium bicarbonate solution + boiling treatment on the one hand and isolating protein technique on the second hand on the growth and hematological performances of broilers. A total of 135 one-day-old $\mathrm{Cobb}_{500}$ broilers, divided into three groups of 45 animals each were randomly allocated to three treatment diets with 3 replicates ( $\mathrm{n}=15 /$ replicate) each per treatment and fed ad libitum with three iso-protein diets: Diet 1 (RTS) given to the Control batch contained soya bean meal and this principal protein source was completely replaced by M. pruriens seeds meal in Diet 2 (RFM) and by protein isolated from M. pruriens in Diet 3 (RIM) given to batches 2 and 3 respectively. Results revealed that FI, ADG, PER, Carcass yield, Hb and Hct were comparable but significantly $(\mathrm{p}<0.05)$ low in broilers fed RFM $(77.01 \mathrm{~g} / 26.16 \mathrm{~g} / 1.99 / 68.69 \%, 11.98 \mathrm{~g} / \mathrm{dL} / 28.46 \%$ respectively) and RIM ( $76.98 \mathrm{~g} / 25.88 \mathrm{~g} / 2.08 / 67.61 \%, 12.05 \mathrm{~g} / \mathrm{dL} / 28.28 \%$ respectively) diets and also in all characteristics of the digestive tract. The inverse trend i.e. highest $(\mathrm{p}<0.05)$ but comparable values of Heart $(0.74 \mathrm{~g} / \mathrm{RFM} ; 0.77 \mathrm{~g} / \mathrm{RIM})$ was observed in these same animals; Birds fed RIM diet registered the lowest $(\mathrm{p}<0.05)$ BWG $(711.04 \mathrm{~g})$ and LW $(799.65 \mathrm{~g})$ but the highest $(\mathrm{p}<0.05)$ FCR (3.45). These results suggest that meal and protein isolate of M. pruriens seeds could be valorised in broiler diet subject to further investigations in growth-finishing phase.
\end{abstract}

Keywords: Mucuna pruriens, Types of Proteins, Broilers, Growth Performances, Blood Indices

\section{Introduction}

Breeding of short-cycle animal species is a survival strategy for the poor $[1,3]$ and it requires few resources and can be practiced by all socio-professional categories. In this case, modern poultry farming is a source of food (meat, eggs) and income for producers; it contributes effectively to ensuring sustainable food security and poverty reduction [4]. In the past decade, consumption of poultry products has increased by $5.8 \%$ per year in developing countries, which is higher than population growth [5]. In Cameroon, poultry farming covers about $14 \%$ of the population's animal protein requirements and generates an annual net profit estimated at around CFA 15 billion [6]. However, the development and profitability of poultry farming face many constraints, particularly feeding.

Feeding accounts for almost 60 to $80 \%$ of modern poultry production costs [7]. In poultry farming, protein deficiency is the major challenge to broiler chicken farmers $[8,9]$. High cost of conventional protein feed ingredients like soybean, fish meal and groundnut cake has caused the search for alternatives plant protein sources such as Mucuna pruriens a wild-type legume grains which has been identified as a potential source of protein and energy for poultry production in developing countries $[9,10]$. Although fairly comparable 
to soybean in terms of amino acid and mineral contents, it is high in protein with a range of $25-36 \%$ and relatively higher in crude fiber $(7-9 \%$ vs. $5-6 \%)$ [11]. Despite the nutritional potential of this legume, its use has been limited by the high concentration of anti-nutritional factors like trypsin, phytates, cyano- genic glucosides, tannins, haemagglutins and L-3,4dehydroxyphenyalanine (L-DOPA) [7, 12]. Severe inhibitions in feed intake, growth rate and incidence of high mortality in broiler chicks fed raw mucuna seeds have been reported [8, 7]. These authors attributed these negative effects to the anti-nutritional factors in the seeds.

Attempts at improving the nutritive value of legume seeds have been made in various ways by different researchers with conflicting results, indicating not more than partial detoxification [12]. Studies on soybean have shown that, despite intensive heat treatment, soybean might still contain $20 \%$ of residual trypsin inhibitor (TIA) activity [13]. Similar observations were made in soybean isolate $[14,15]$.

Ingestion of numerous dietary components has been found to have measurable effort on some blood constituents. Therefore, blood provides a valuable medium for clinical investigation of nutritional status of individual [16]. This study reports the effect of dietary inclusion of presoaking in water then in sodium bicarbonate solution + boiling treatment on the one hand and isolating protein technique on the second hand of $M$. pruriens seeds on the growth and hematological performances of broilers.

\section{Materials and Methods}

\subsection{Study Site}

The study was conducted at the University of Ngaoundere, capital of the Adamawa region in Cameroon. This town is located between the 6th and 8th degrees of North latitude and between the 11th and 15th degree of East longitude on the Adamawa ridge. Ngaoundere is a transition zone between the northern lowlands and the southern Cameroon plateau. This position gives it a Sudano-Guinean climate with a rainy season of 8 months, from April to November and a dry season of 4 months, from December to March. The plant cover consists of Sudano-Guinean shrub savannah. The annual rainfall varies between 900 and $1500 \mathrm{~mm}$. Average temperatures vary between 23 and $25^{\circ} \mathrm{C}$. The region of Adamawa, thanks to its climate and its vegetation cover, is a zone of strong potentialities.

\subsection{Sampling and Production of Meal and Protein Isolate of Mucuna Seeds}

Mature seeds of $M$. pruriens var. Cochinchinensis were manually rid of infested seeds and impurities. As for Mucuna meal, seeds were treated as recommended [4] with some modifications. Seeds were soaked in tap water $(1: 10, \mathrm{w} / \mathrm{v})$ for $48 \mathrm{~h}$, dehulled manually and requenched in a solution of sodium bicarbonate $\left(\mathrm{NaHCO}_{3}\right)$ at a concentration of $0.8 \%$ for 24 hours. After this, the seeds were boiled in clean water for 30 minutes and sundried for 2 days, after which they were milled and ground to particle size of 1.00-1.70 mm using a commercial milling machine and the meal was stored in plastic bags for incorporation into the experimental diet.

Protein isolates of $M$. pruriens were prepared from raw and processed seeds samples following the associated methods $[17,4]$ with some modifications. The seeds were soaked in a volume of water so that they were completely submerged for 48 hours, the water was changed after 24 hours. Then, they were rinsed successively 3 times with drilling water. These seeds were ground using a wheel mill and the resulting paw was collected in a $13 \mathrm{~L}$ clear white bucket to which was added 1: 4 ratio water $(\mathrm{w} / \mathrm{v})$. The $\mathrm{pH}$ was adjusted between 8 and 8.5 with $2 \mathrm{~N} \mathrm{NaOH}$ and the whole was then homogenized at $120 \mathrm{rpm}$ for three hours using a PROLABO brand arm shaker. The mixture was allowed to stand for 24 hours. The supernatant was collected and set aside. The residue was extracted again according to the same protocol but the mixture was homogenized for one hour and left to stand for two hours, then filtered. The two supernatants obtained were mixed and the $\mathrm{pH}$ was adjusted between 4 and 4.5 with $2 \mathrm{~N}$ acetic acid by homogenizing the solution, then leave to stand for 16 hours. This allowed the precipitation of the proteins and the isoelectric precipitate obtained was filtered, drained and finally dried for 12 hours, and stored until required.

\subsection{Experimental Diets and Animal Management}

Three iso-nitrogenous diets were formulated to meet the nutritional needs of broilers in the starter phase with complete substitution of soya bean such that Diet 1 contained soybean meal (7\%) and served as the control (RTS). Diets 2 contained Mucuna meal 16\% (RFM) and Diet 3 contained protein isolate meal of Mucuna (5\%) (Table 1). Each of the diets representing a treatment was analyzed for proximate composition [18].

Table 1. Centesimal and chemical composition of experimental diets.

\begin{tabular}{llll}
\hline Ingredients & RTS & RFM & RIM \\
\hline Maize & 50 & 45 & 56 \\
Corn bran & 18 & 14 & 14 \\
Soya bean meal & 07 & 00 & 00 \\
Mucuna meal & 00 & 16 & 00 \\
Protein isolate of Mucuna & 00 & 00 & 05 \\
Fish meal & 14 & 14 & 14 \\
Cotton cake & 05 & 05 & 05 \\
Bone meal & 01 & 01 & 01 \\
MNVC 5\% & 05 & 05 & 05 \\
Total & 100 & 100 & 100 \\
Calculated chemical composition & & & \\
Metabolisable Energy (Kcal/Kg DM) & 3144 & 3172 & 3196 \\
Crude proteins (\% DM) & 21.2 & 21.4 & 21.7 \\
Energy/Proteins & 148.3 & 148.2 & 147.2 \\
Fats (\%DM) & 5.4 & 4.8 & 4.4 \\
Crude fibres (\%DM) & 5.0 & 6.1 & 4.3 \\
\hline
\end{tabular}

CMAV 5\%: Mineral Nitrogen and Vitamin Complex: $P B=40 \%$; Calcium $=8 \%$; Phosphore $=2.05 \%$; Lysne $=3.3 \%$; Methionine $=2.40 \%$; $\mathrm{EM}=2078 \mathrm{kcal} / \mathrm{kg} ; \mathrm{DM}=$ Dry Matter; RTS= meal-based diet of soybean; $\mathrm{RFM}=$ meal-based diet of $M$. pruriens seeds; RIM= protein isolate-based diet of $M$. pruriens seeds. 
One hundred and thirty five (135) 1-day old Cobb 500 broiler chicks were balanced for weight and randomly assigned to the three dietary treatments in a complete randomized design. Each treatment group of 45 birds was further subdivided into three replicates of 15 chicks each and kept in a cage (size $80 \mathrm{x}$ $50 \times 60 \mathrm{~cm}$ ). The chicks were raised on litter (wood shavings) of good absorbent quality and artificial light (electric bulb) provided to encourage the birds to eat at night. Feed and water were provided ad libitum on a daily basis and the birds were subjected to standard management procedure. Feed intake and body weights were recorded weekly. The chicks were vaccinated against Newcastle disease (HitchnerB1®) and infectious bronchitis (H120®).

\subsection{Growth Performance Evaluations}

Weekly weights were registered to establish growth curve. The weight of the feed given, feed leftover and also weight of the birds were recorded weekly and then the feed intake was determined by subtracting the leftover feed from total feed offered. The feed intake (FI), body weight gains (BWG), and feed conversion ratio (FCR) [19] and the protein efficiency ratio (PER) [11] were calculated using the following formula:

$$
\begin{gathered}
\text { Feed Intake }(F I)=\frac{\text { Total feed given }(g)-F e e d \text { leftover }(g)}{\text { Experimental period }(\text { Number of days })} \\
\text { Body weight gain }(B W G)=\frac{\text { Final body weight }(g) \text {-Initial body weight }(g)}{\text { Experimental period }(\text { Number of days })} \\
\text { Feed conversion ratio }(F C R)=\frac{\text { Feed intake }(g)}{\text { Body weight gain }(g)} \\
\text { Protein efficiency ratio }(P E R)=\frac{\text { Body weight gain }(g)}{\text { Protei intake }(g)}
\end{gathered}
$$

\subsection{Carcass and Organ Evaluations}

At the end of the 21 days feeding trial, 9 birds per treatment (3 per replicates) were randomly selected, fasted overnight, then slaughtered, dressed and eviscerated. Weights of the visceral organs and carcass were recorded and expressed as percentage of live weight.

\subsection{Hematology Indices}

Blood sample of each sacrificed bird was collected into tubes pretreated with ethylene diamine tetra acetic acid (EDTA) as anti-coagulant. Hematological analyses were performed on blood samples using an automated hematology analyzer (Humacount; Human, Weisbaden, Germany). The recorded parameters were white blood cells, lymphocytes, granulocytes, red blood cells, hemoglobin, hematocrit and platelets.

\subsection{Statistical Analysis}

Data collected were subjected to analysis of variance as described for completely randomized design [20], and differences between treatment means were separated using Duncan's New Multiple Range Test [21].

\section{Results}

\subsection{Effect of Meal and Protein Isolate of M. Pruriens on Growth Performances of Broilers in Starter Phase}

\subsubsection{Life Weight Evolution}

The evolution of live weight in the experimental groups was comparable and was linear during the 3 weeks experiment (Figure 1). No death was reported in any groups throughout the experimental period.

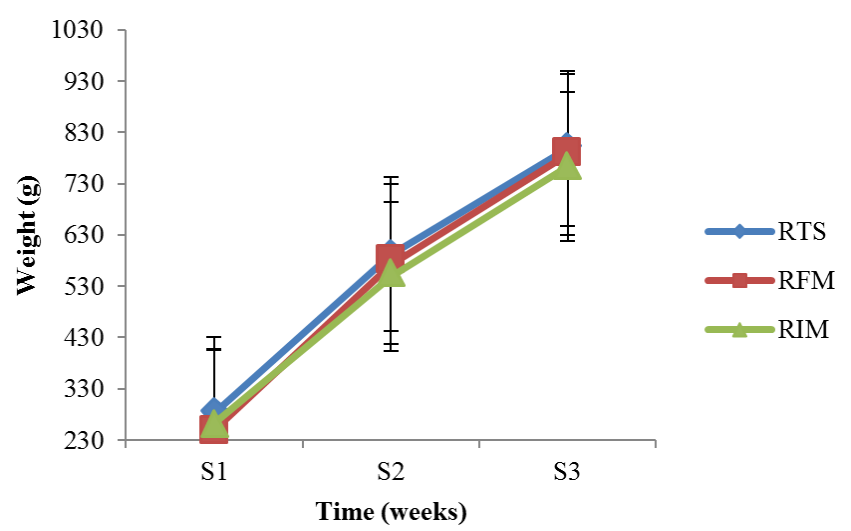

Figure 1. Weight evolution of broiler chicks in starter phase according to experimental diets.

RTS: meal-based diet of soybean; RFM: meal-based diet of $M$. pruriens; RIM: meal-based diet of protein isolate of $M$. pruriens

\subsubsection{Growth Characteristics}

Table 2 shows the growth characteristics of chicks in the start-up phase according to experimental diets. There were significant $(p<0.05)$ differences in all the performance characteristics measured. Animals in supplemented batches (RFM and RIM) recorded comparable but lower $(p<0.05)$ FI and ADG, those in RIM batch recorded the lowest $(\mathrm{p}<0.05)$

\begin{tabular}{|c|c|c|c|c|}
\hline Parameters & RTS & RFM & RIM & $\mathbf{p}$ \\
\hline Feed intake $(\mathrm{FI})(\mathrm{g})$ & $78.63 \pm 0.50^{\mathrm{a}}$ & $77.01 \pm 0.86^{\mathrm{b}}$ & $76.98 \pm 0.77^{b}$ & 0.04 \\
\hline Body Weight Gain (BWG) (g) & $733.59 \pm 0.15^{\mathrm{a}}$ & $715.06 \pm 01.03^{\mathrm{b}}$ & $711.04 \pm 0.30^{\mathrm{c}}$ & 0.00 \\
\hline Average Daily Gain (ADG) (g) & $27.94 \pm 1.79^{\mathrm{a}}$ & $26.16 \pm 0.88^{b}$ & $25.88 \pm 0.33^{\mathrm{b}}$ & 0.00 \\
\hline Feed conversion ratio (FCR) & $2.82 \pm 0.21^{\mathrm{b}}$ & $2.60 \pm 0.47^{\mathrm{b}}$ & $3.45 \pm 0.01^{\mathrm{a}}$ & 0.03 \\
\hline Protein efficiency ratio (PER) & $2.68 \pm 0.02^{\mathrm{a}}$ & $1.99 \pm 0.02^{\mathrm{b}}$ & $2.08 \pm 0.03^{b}$ & 0.01 \\
\hline
\end{tabular}
BWG and the highest $(\mathrm{p}<0.05)$ FCR. Birds in control group registered the highest $(\mathrm{p}<0.05)$ PER.

Table 2. Growth characteristics of broilers in starter phase according to experimental diets.

a, b, c: Averages with the same letters on the same line are not significantly different at the 5\% level; RTS: meal-based diet of soybean; RFM: meal-based diet of M. pruriens; RIM: meal-based diet of protein isolate of $M$. pruriens; $\mathrm{p}=$ probability. 


\subsubsection{Characteristics of Carcass and Organs of Broilers in Starter Phase}

The organ characteristics of broilers fed the experimental diets as recorded in the study are presented in Table 3. Variations obtained in liver, kidney, spleen and gizzard were not significant $(\mathrm{p}>0.05)$. Broilers fed RIM and RTS diets registered the lowest $(\mathrm{p}<0.05)$ live weight and the highest $(\mathrm{p}<0.05)$ carcass yield respectively. Birds fed RFM and RIM diets register heavier $(\mathrm{p}<0.05)$ heart compare to the control.

Table 3. Some characteristics of organs of broilers in starter phase according to experimental diets.

\begin{tabular}{lllll}
\hline & RTS & RFM & RIM & p \\
\hline Live weight (g) & $853,16 \pm 03.16^{\mathrm{a}}$ & $802.21 \pm 04.28^{\mathrm{b}}$ & $799.65 \pm 02.46^{\mathrm{c}}$ \\
Carcass yield (\%) & $70,47 \pm 0.50^{\mathrm{a}}$ & $68.69 \pm 1.29^{\mathrm{b}}$ & $67.61 \pm 1.13^{\mathrm{b}}$ & 0.00 \\
Heart (g) & $0.58 \pm 0.88^{\mathrm{b}}$ & $0.74 \pm 0.12^{\mathrm{a}}$ & $0.77 \pm 0.09^{\mathrm{a}}$ & 0.00 \\
Liver (g) & $2.78 \pm 1.12$ & $2.84 \pm 0.26$ & $2.98 \pm 0.29$ & 0.02 \\
Kidney (g) & $0.39 \pm 0.04$ & $0.41 \pm 0.01$ & $0.40 \pm 0.03$ & 0.33 \\
Spleen (g) & $0.14 \pm 0.04$ & $0.12 \pm 0.01$ & $0.12 \pm 0.02$ & 0.06 \\
Gizzard (g) & $3.16 \pm 0.26$ & $3.12 \pm 0.20$ & $3.39 \pm 0.41$ & 0.28 \\
\hline
\end{tabular}

${ }^{\mathrm{a}, \mathrm{b}, \mathrm{c}}$ : Averages with the same letters on the same line are not significantly different at the 5\% level; RTS: meal-based diet of soybean; RFM: meal-based diet of M. pruriens; RIM: meal-based diet of protein isolate of M. pruriens; $\mathrm{p}=$ probability

\subsubsection{Characteristics of the Digestive Tract of Broilers in Starter Phase}

All the parameters measured were identical between

broilers receiving RFM and RIM diets but with lower $(\mathrm{p}<0.05)$ values compare to the control (Table 4$)$.

Table 4. Characteristics of the digestive tract of broilers in starter phase according to experimental diets.

\begin{tabular}{llll}
\hline Parameters & RTS & RFM & RIM \\
\hline Weight of digestive tract $(\mathrm{g})$ & $148.16 \pm 1.56^{\mathrm{a}}$ & $123.86 \pm 0.31^{\mathrm{b}}$ & $124.12 \pm 0.03^{\mathrm{b}}$ \\
Weight of intestine $(\mathrm{g})$ & $74.01 \pm 1.30^{\mathrm{a}}$ & $71.02 \pm 1.25^{\mathrm{b}}$ & $71.32 \pm 1.04^{\mathrm{b}}$ \\
Lenght of intestine $(\mathrm{cm})$ & $171.83 \pm 1.54^{\mathrm{a}}$ & $164.16 \pm 3.10^{\mathrm{b}}$ & 0.01 \\
Intestine Density $(\mathrm{cm})$ & $43.32 \pm 1.09^{\mathrm{a}}$ & $38.23 \pm 0.22^{\mathrm{b}}$ & 0.04 \\
\hline
\end{tabular}

a, b: Averages with the same letters on the same line are not significantly different at the 5\% level; RTS: meal-based diet of soybean; RFM: meal-based diet of M. pruriens; RIM: meal-based diet of protein isolate of $M$. pruriens; $\mathrm{p}=$ probability.

\subsection{Effect of Meal and Protein Isolate of M. Pruriens Seeds on Hematological Parameters of Broilers in Starter Phase}

Results of the hematological characteristics of broilers fed experimental diets have shown that the rates of Hb and Hct were lower $(\mathrm{p}<0.05)$ but comparable in groups fed processed Mucuna seeds (Table 5).

Table 5. Blood parameters of broilers in starter phase according to experimental diets.

\begin{tabular}{|c|c|c|c|c|}
\hline & RTS & RFM & RIM & $\mathbf{p}$ \\
\hline White blood cell (WBC) $\left(\times 10^{9} / \mathrm{L}\right)$ & $117.88 \pm 5.35$ & $113.75 \pm 8.60$ & $116.08 \pm 8.04$ & 0.63 \\
\hline Red blood cell $(\mathrm{RBC})\left(\mathrm{x} 10^{12} / \mathrm{L}\right)$ & $2.41 \pm 0.11$ & $2.26 \pm 1.14$ & $2.28 \pm 1.11$ & 0,11 \\
\hline Hemoglobin $(\mathrm{g} / \mathrm{dL})$ & $12.86 \pm 0.15^{\mathrm{a}}$ & $11.98 \pm 0.23^{\mathrm{b}}$ & $12.05 \pm 0.20^{\mathrm{b}}$ & 0.01 \\
\hline Hematocrit $(\%)$ & $31.18 \pm 1.31^{\mathrm{a}}$ & $28.46 \pm 1.14^{\mathrm{b}}$ & $28.28 \pm 1.38^{b}$ & 0.00 \\
\hline Blood platelets (Plts) $\left(\times 10^{9} / \mathrm{L}\right)$ & $5.16 \pm 0.55$ & $5.28 \pm 0.46$ & $4.98 \pm 0.83$ & 0.27 \\
\hline
\end{tabular}

a, b: Averages with the same letters on the same line are not significantly different at the 5\% level; RTS: meal-based diet of soybean; RFM: meal-based diet of M. pruriens; RIM: meal-based diet of protein isolate of $M$. pruriens; $\mathrm{p}=$ probability

\section{Discussion}

Protein is very critical in animal diet formulation because it is the most limiting and expensive nutrient and the best indicator of diet quality and animal performances [22]. The non-significant weight evolution observed in all broilers in this study in all treatments is an indication that such protein types (meal and protein isolate of $M$. pruriens seeds) were of good quality and also were tolerable by the broiler chicks. Likewise, the lack of mortality among all broilers may suggest that the methods of processing were effective in removing or detoxifying anti-nutritional factors (ANFs) contained in Mucuna seeds at a safe level for animals.
The complete substitution of soybean meal by meal and protein isolate of $M$. pruriens significantly $(\mathrm{p}<0.05)$ impaired weight evolution and growth characteristics of animals subjected to these diets. Our findings corroborate those reported in broilers fed processed Mucuna seeds and incorporated into three levels $12.5,18.75$ and $30 \%$ in broilers diets to replace soybean meal [23] and in starter broilers fed self-formulated and commercial feeds [24]. These authors attributed the growth depression to residues of antinutritional and toxic factor components (tannins, hydrocyanic acid, L-DOPA, phenolic compounds, phytates, lectins) still present in the meal and protein isolate of Mucuna seeds that unbalance the absorption of nutrients and which tended to impair protein utilization, thereby reducing the nutritional 
value of the seeds protein. The low FI in broilers fed meal and protein isolate of Mucuna can be attributed to the presence of tannins which have been reported to reduce palatability of the diet due to its astringent property as a result of its ability to bind with protein of saliva and mucosa membranes $[25,26]$. Our results are in consistent with those reported in laying hens and broilers fed Mucuna seed meal [11]. The decrease in FI resulted in decreased BWG [11]. Contents of residual ANFs detected in meal and protein isolate of Mucuna seeds could be responsible for the depression in the BWG and elevated FCR. The highest FCR of 3.45 registered in broilers fed RIM diet showed that there was a higher feed intake and the birds were gaining less and this indicates a poor feed efficiency and low feed utilization of RIM diet as compared to other diets [27]. The FCR values in all treatments in this experiment were comparable to values of other studies $(2.12,3.23,2.85,2.51$ and 2.38) [28] and $(2.03,2.01,2.04,2.29,2.38$ and 2.45) [29] in broilers fed processed Mucuna seeds. But FCR values of this study were low than those reported (4.60 and 4.63) in broilers fed processed Mucuna seeds [23].

However, FCR alone is not enough to predict the effectiveness of a protein since the amount of food ingested does not always reflect the amount of protein ingested or assimilated. Hence, other growth parameters taking into account the amount of protein ingested such as Protein Efficiency Ratio (PER) which is a parameter of animal growth has been determined. PER values of this study compare favorably with those of previous studies $(2.14,2.15$, $2.12,1.89,1.82$ and 1.76) in broilers fed different levels $(0$, $20,40,60,80$ and 100\%) of Mucuna seeds meal [29] and $(2.36,1.55,1.76,1.95$ and 2.10$)$ in broilers fed processed Mucuna seeds [28]. These results indicate that proteins of meal and protein isolate of $M$. pruriens seeds can promote growth of broilers, given the comparable weight evolution in all batches.

The decrease in ADG in animals receiving test diets suggested that anti-nutritional factors still present in RFM and RIM diets reduced the bioavailability of nutrients during digestion. These substances act either by complexing nutrients and preventing their absorption along the gastrointestinal tract, or by inhibiting the activity of enzymes responsible for their hydrolysis, or by inducing toxicity at high doses [30]. The ADG (27.94, 26.16 and $25.88 \mathrm{~g}$ ) obtained at the end of this experiment is higher than the results $(20.84 \mathrm{~g} ; 16.08 \mathrm{~g} ; 10.76 \mathrm{~g})$ obtained on broilers fed processed Mucuna seeds [23]. The variety, processing methods used and the different levels of incorporation of processed Mucuna seeds could explain these differences.

The low $(\mathrm{p}<0.05)$ but comparable Carcass yield observed in treated groups are evidence of the detrimental effect of the residual ANFs still present in Mucuna meal and protein isolate responsible for the significant $(\mathrm{p}<0.05)$ depression in the weight gain in the broiler chicks [11, 23]. Although Mucuna seeds were processed, many studies have shown that even though processing tends to have a positive influence in the reduction of the anti-nutritional factor concentrations in the seeds or leaves of $M$. pruriens so as to improve broilers performances, it does not entirely eliminate them [31].

The relative weights of individual organs (liver, kidney, spleen and gizzard) did not vary significantly showing that meal and protein isolate of Mucuna was not detrimental to the birds. However, the significant $(p<0.05)$ increase in heart weight observed in broilers fed processed Mucuna seeds could also be the result of more intense work on this organ which has to pump a lot of oxygenated blood to help detoxify toxins in any material [32].

The development of the gastrointestinal tract is a priority phenomenon in the general development of the chick. The marked reduction in the length of intestines in the batches fed processed Mucuna seeds diets could be due to the presence of two classes of ANFs frequently found in leguminous seeds known as tannins and lectins [11, 12]. Lectins exert their deleterious antinutritional effects via reduced nutrient absorption following extensive structural and functional disruption of the intestinal villi. These ANFs possibly caused a shedding of the outer membrane of the gastrointestinal tract and decreased villus length, with consequent reduction in the surface area for absorption in the small intestine [11]. Tannins meanwhile which are polymeric phenols are strongly proteophillic, may bind to proteins of the ileal epithelium, thus disrupting digestive and absorptive processes in the intestine. This will account for the remarkable increase in the loss, through the faeces, of proteins and amino acids [8, 7].

The haematopoietic system is one of the most sensitive targets for toxic chemicals and an important index of physiological and pathological status in human and animal [33]. The significant decrease $(p<0.05)$ in the hemoglobin concentration of broilers subjected to dietary processed Mucuna could be explained by the decrease in erythropoiesis during the hemoglobin synthesis. This decrease could also be attributed to the iron deficiency (iron enters into the constitution of hemoglobin) caused by anti-nutrients as phytates because they are known for their ability to complex iron which is essential for erythropoiesis.

The hematocrit represents the percentage of red blood cells in the blood [34]. The decrease in the rate of hematocrits in birds fed processed Mucuna could be due to the decrease in the bioavailability of the nutrients necessary for the synthesis of red blood cells because an increase in hematocrit results in better transport and an increase in the bioavailability of nutrients necessary for growth and an increase in the number of red blood cells [22]. The highest hemoglobin and hematocrit levels $(12.8663 \mathrm{~g} / \mathrm{dL}$ and $31.18 \%)$ in broilers of the control batch observed in this study are close to those reported by [35] in broilers fed the diets containing $24 \%$ green beans with $(12.86 \mathrm{~g} / \mathrm{dL}$ and $36.76 \%$ respectively) and without $(12.90 \mathrm{~g} / \mathrm{dL}$ and $34.43 \%$ respectively) enzyme. However, these results corroborate those reported on rats fed with flour-based foods from the black, white, striped variety and Leckifood from the striped and white variety of Mucuna [36] and on rats subjected to the diet containing Mucuna milks who also observed a reduction in the hemoglobin concentration and in the level of hematocrit [30]. 


\section{Conclusion}

This study revealed that seeds meal $(27.60 \% \mathrm{CP})$ and protein isolate $(91.02 \%)$ of $M$. pruriens could be considered as good source of proteins and as feed ingredients in poultry feeding. Processing techniques used have shown not to be effective in reducing the toxic effects after processing with the observed adverse effects on growth and some hematological parameters of broilers. Nevertheless, their level of incorporation was tolerated by broiler chicks. Therefore, further studies to examine their impact on biochemical and oxidative stress parameters during the same starter phase are suggested.

\section{Acknowledgements}

The authors are grateful for the facilities in the laboratory of Biophysics, Biochemistry and Nutrition Laboratory (LABBAN) of the National School of Agro-Industrial Sciences, University of Ngaoundere.

\section{References}

[1] N. N. Mweugang F. Tendonkeng, E. Miégoué, F. E. N. Matumuini, G. T. Zougou, F. A. Fonteh, B. Boukila et E. T. Pamo, "Effets de l' iinclusion de feuilles de manioc (Manihot esculenta Crantz) dans la ration sur les performances de reproduction du cobaye (Cavia porcellus $\mathrm{L}$.) local camerounais" Int. J. Biol. Chem. Sci., vol. 10, no. 1, pp. 269-280, 2016.

[2] N. N. Mweugang, F. Tendonkeng, N. E. F. Matuimini, E. Miégoué, B. Boukila and T. E. Pamo, "Influence of the inclusion of graded levels of cassava leaf meal in the diet on post partum weight and pre- weaning growth of guinea Pigs (Cavia Porcellus L.)," Int. J. Agric. Innov. Res., vol. 2, no. 6, pp. 939-945, 2014.

[3] E. Miegoue, F. Tendonkeng, N. N. Mweugang, J. Lemoufouet, M. V. Tatang, P. Ntsafack, M. Mouchili and E. Pamo, "Effect of Inclusion levels of Arachis glabrata in the diets on the ingestion and in vivo digestibility of Panicum maximum in guinea pigs (Cavia porcellus)," Int. J. Vet. Sce. Technol. vol. 3 (1), pp. 026-032, 2018.

[4] O. Rachel Rakotomanana, R. T. Donnah, J. E. Razafindralambo and R. J. Razafindralambo, "Graines de mucuna traitées par du bicarbonate de sodium pour 1, alimentation des animaux à cycle court (Région Androy)," Programme européende sécurité alimentaire et nutritionnelle dans les régions sud et sud-est de Madagascarasara/ASARA, p. 22 pages, 2016.

[5] E. Sonaiya and S. Swan, "Production en Aviculture Familiale," Rome, 2004.

[6] SDDFEC, Schéma directeur pour le developpement des filieres de l 'élevage au Cameroun, vol. II. Cartographie des filières. Ministère de l'Elevage, des Pêches et des Industries Animales. République du Cameroun. 82p. 2009.

[7] C. D. Tuleun and F. Igba, "Growth and carcass characteristics of broiler chickens fed water soaked and cooked velvet bean (Mucuna utilis) meal," African J. Biotechnol., vol. 7, no. 15, pp. 2676-2681, 2008.
[8] L. B. Carew D. Hardy, J. Weis, F. Alster, S. A. Mischler, A. Gernat and E. I. Zakrzewska, "Heating raw velvet beans (Mucuna pruriens) reverses some anti-nutritional effects on organ growth, blood chemistry, and organ histology in growing chickens," Trop. Subtrop. Agroecosystems, vol. 1, pp. 267-275, 2003.

[9] M. Dahouda S. S. Toleba, A. K. I. Youssao, A. A. Ali Mama, R. K. Dangou-Sapoho, G. Ahounou, A. Hambuckers and J-L. Hornick, "The effects of raw and processed Mucuna pruriens seed based diets on the growth parameters and meat characteristics of benin local guinea fowl (Numida meleagris, L)," Int. J. Poult. Sci., vol. 8, no. 9, pp. 882-889, 2009.

[10] V. Vadivel and M. Pugalenthi, "Studies on the incorporation of velvet bean (Mucuna pruriens var. utilis) as an alternative protein source in poultry feed and its effect on growth performance of broiler chickens," Trop. Anim. Health Prod., vol. 42, no. 7, pp. 1367-1376, 2010.

[11] I. A. Iyayi and V. O. Taiwo, "The effect of diets incorporating mucuna (Mucuna pruriens) seed meal on the performance of laying hens and broilers," Trop. Subtrop. Agroecosystems, vol. 1, pp. 239-246, 2003.

[12] I. A. Emiola, A. Ologhobo, J., Akinlade, S. O. Adedeji and O. Bamgbabe, "Effect of inclusion of differently processed Mucuna utilis seed meal on performance characteristics of broilers," Trop. Anim. Health Prod., vol. 6, no. June, pp. 13-21, 2003.

[13] M. Friedmann, D. L. Brandon, Babes and T. Hymowitz, "Effects of heat on the nutritional quality of soybean cultivars. IN: (Friedmann, M., Ed) Nutritional and Toxicological consequences of food processing Plenum Press, New York," pp. 339-361, 1991.

[14] A. Van Amevongen, V. Ostafe,, M. M. T Meijewo, H. Guppen, G. Meeradink, L. B. J. M. Berendsen, M. Koets and J. H. Wichers, "Specific-immuno-(chymo) trypsin- inhibitor assays for determination of (residual) activity of BowmanBirk or Kunitz soybean inhibitors. In: Jansman, A. J. M., Hill, G. D. and Huisman, J. Recent advances of research in Antinutritional factors of Legumes s," pp. 33-37, 1998.

[15] R. Alonso, A. Aguirre and F. Marzo, "Effects of extrusion and traditional processing methods on antinutrients and in vitro digestibility of protein and starch in faba and kidney beans," Food Chem., vol. 68, no. 2, pp. 159-165, 2000.

[16] A. Z. Aderolu, E. A. Iyayi and A. A. Onilude, "Performance, organ relative weight, serum and haematology parameters in broilers finisher fed biodegraded brewers dried grain," Pakistan J. Nutr., vol. 6, no. 3, pp. 204-208, 2007.

[17] B. Kom, C. Bernard, N. Njintang, and R. Kamga, "Production of Mucuna pruriens (var. utilis) Proteins Isolates Using Central Composite Design and Effect of Drying Techniques on Some Properties," Chem. Sci. Int. J., vol. 20, no. 1, pp. 1-12, 2017.

[18] $A O A C$, Association of Official Analytical Chemists. Official methods of analysis, 15th edition. Washington, DC. 1990.

[19] J. Del Carmen, A. G. Gernat, R. Myhrman, and L. B. Carew, "Evaluation of raw and heated velvet beans (Mucuna pruriens) as feed ingredients for broilers," Poult. Sci., vol. 78, no. 6, pp. 866-872, 1999.

[20] R. G. D. Steel and J. H. Torrie, "Principles and Procedures of Statistics. A Biometric Approach.(2nd ed.). McGraw-Hill Publishers, New York.," pp. 1-633, 1980. 
[21] D. B. Duncan, "New Multiple Range Test. Biometrics," vol. 11, pp. 1-42, 1955.

[22] M. Salahuddin, M. A. Miah and N. Ahmad, "Effects of protein and vitamin ADE on growth performance and haemato-biochemical profile in broiler," Bangladesh J. Vet. Med., vol. 10, no. 1-2, pp. 9-14, 2012.

[23] A. B. Aboh, S. E. P. Mensah, G. S. T. Atchade and G. A. Mensah, "Performance pondérale et caractéristiques des carcasses des poulets de chair alimentés avec des rations alimentaires à base de graines de Mucuna pruriens," Int. J. Biolögical Chem. Sci., vol. 5, no. 6, pp. 2306-2316, 2011.

[24] E. B. Onwujiariri and P. C. Jiwuba, "Comparative evaluation on growth performance of starter broilers fed self-formulated and commercial feeds," Int. J. Agric. Manag. Technol., vol. 3, no. 2, pp. 158-161, 2019.

[25] M. Dahouda, S. S. Toléba, A. K. I. Youssao, A. Youssao, A. hambuckers; R. Dangou-Sapoho, G. B. Martin, M. Fillet and J. -L. Hornick, "Nutrient digestibility of Mucuna (Mucuna pruriens var. utilis) bean in guinea fowl (Numida meleagris, L): Effects of heat treatment and levels of incorporation in diets,” Br. Poult. Sci., vol. 50, no. 5, pp. 564-572, 2009.

[26] U. S. Tjetjoo, C. J. Moreki, S. J. Nsoso and O. R. Madibela, "Growth performance of guinea gowl fed diets containing yellow maize, millet and white sorghum as energy sources and raised under intensive system," Pakistan J. Nutr., vol. 12, no. 4, pp. 306-312, 2013.

[27] F. Hlabano, "Growth performance of indigenous chickens fed graded levels of toasted velvet bean (mucuna pruriens) meal," Thesis, Faculty of Natural Resource Management and Agriculture, Midlands State University, 54p. 2017.

[28] C. D. Tuleun, B. Offia and I. D. I. Yaakugh, "Comparative cerformance of croilerced ciets containing raw and processed Mucuna Seed Meal," Int. J. Poult. Sci., vol. 9, no. 11, pp. 1056-1062, 2010.
[29] V. Vadivel, M. Pugalenthi, A. Doss and T. Parimelazhagan, "Evaluation of velvet bean meal as an alternative protein ingredient for poultry feed," Animal, vol. 5, no. 1, pp. 67-73, 2010.

[30] Y. D. Mang, Y. N. Njintang, B. A. Abdou, J. Scher, C. Bernard and M. C. Mbofung, "Dehulling reduces toxicity and improves in vivo biological value of proteins in vegetal milk derived from two mucuna (Mucuna pruriens L.) seeds varieties," J. Food Sci. Technol., vol. 53, no. 6, pp. 25482557,2016

[31] B. T. Sese, M. Okpeku and I. Patani, "Tropical Velvet Bean (Mucuna Utilis) Leaf Meal as Unconventional Protein Supplement in the Diet of Broiler Tropical Velvet Bean (Mucuna Utilis) Leaf Meal as Unconventional Protein Supplement in the Diet of Broiler," J. Anim. Sci. Adv., vol. 3, no. 11, pp. 575-583, 2013.

[32] U. Okpanachi, P. U. Boyi, C. F. Egbu and A. Oyibo, "Performance and Internal Organ Characteristics of Broiler Chickens Fed Urea-Treated and Untreated Rice Milling Waste," vol. 1, no. 4, pp. 130-135, 2015.

[33] J. T. Mukinda and J. A. Syce, "Acute and chronic toxicity of the aqueous extract of Artemisia afra in rodents," $J$. Ethnopharmacol., vol. 112, pp. 138-144, 2007.

[34] N. N. Etim, M. E. Williams, U. Akpabio and E. E. A. Offiong, "Haematological parameters and factors affecting their values," Agric. Sci., vol. 2, no. 1, pp. 37-47, 2014.

[35] A.-M. A. Mamdouh, "Effect of using green beans processing by-products with and without enzyme supplementation on broilers performance and blood parameters," J. Agrobiol., vol. 30, no. 1, pp. 43-54, 2014.

[36] M. J. Ngatchic, Y. N. Njintang, J. E. Oben and C. Mbofung, "Protein quality and antigrowth effect of protein isolate of Mucuna (Mucuna Pruriens) and Canavalia (Canavalia ensiformis) seeds," Sch. Acad. J. Biosci., vol. 1, no. 5, pp. 183-191, 2013. 